\title{
Language Without Borders (English) Program: A Study on English Language Ideologies
}

\section{Programa Idiomas sem Fronteiras (Inglês): um estudo sobre ideologias da língua inglesa}

Taisa Pinetti Passoni*

*Federal University of Technology-Paraná (UTFPR), Pato Branco, Paraná / Brazil taisapassoni@utfpr.edu.br

https://orcid.org/0000-0001-7819-1327

\begin{abstract}
This paper presents the synthesis of a study on the English language ideologies (ELI) underlying the Federal Program entitled "Languages without Borders-English" (LwBE). The investigation draws on texts from the legal, educational, and journalistic spheres about the enactment of the Program. Using NVivo 11 software, these texts were stored and categorized in the light of the Policy Cycle Approach and Critical Discourse Analysis. The overlapping of six ELI - standard language, English language as a commodity, native-speakerism, instrumentalist, global language and linguistic imperialism - is conceived as a common trait of LwBE in discourses, displaying tensions between the ratification and the questioning of English hegemony in the language policy engendered by the Program, within the context of the internationalization of Brazilian higher education.
\end{abstract}

KEYWORDS: Languages without Borders; language policy; internationalization; language ideology; English language.

RESUMO: Este artigo apresenta a síntese de um estudo sobre ideologias da língua inglesa (ILI) que permeiam o Programa Federal "Idiomas sem Fronteiras - Inglês" (IsFI). A pesquisa analisa textos das esferas legal, educacional e jornalística que tratam da realização do Programa. Utilizando o software NVivo 11, os textos foram armazenados e categorizados segundo pressupostos da Abordagem do Ciclo de Políticas e da Análise de Discurso Crítica. O entrelaçamento de seis ILI - língua padrão, língua inglesa como mercadoria, falante nativo, instrumentalista, língua global e imperialismo linguístico - é tomado como característico do IsFI em discursos marcados por tensões entre ratificação e questionamento da hegemonia do inglês na política linguística engendrada pelo Programa, no âmbito da internacionalização do ensino superior brasileiro.

PALAVRAS-CHAVE: Idiomas sem Fronteiras; política linguística; internacionalização; ideologia linguística; língua inglesa. 


\section{Introduction}

The internationalization of higher education (IHE) combines policies and programs proposed by governments or educational institutions to enhance academic collaboration among countries (ALTBACH, 2006). It should entail international, intercultural, or global dimensions in its initiatives (KNIGHT, 2004), seeking to improve education and research, as well as increase investments for local and global development (JONES, 2013). ${ }^{1}$

In Brazil, IHE dates back to the 1960's, when the Exchange for Undergraduate Students Program (Estudantes-Convênio de Graduação, PEC-G) was proposed. Based on bilateral agreements, PEC-G focuses on the professional qualification of students from developing nations, among which African nations have long stood out (BIZON, 2013). However, the IHE in Brazil has been strongly attached to outward mobility for qualifications in human resources. In the 1970's, the National Plans of Graduate Programs provided the opportunity for university professors and researchers to receive qualifications overseas, as the country had very few stricto sensu postgraduate courses at the time (MOROSINI, 2006). Since then, Brazilian academia has been defined by its academic profile, overlooking its potential as an formulator of industrial innovations (SILVA, 2012).

Following an upward trend since the early 2000's, Brazil became the sixth largest economy in the world in 2011. This achievement stemmed from the stabilization of the national currency, "Real", reinforced by the reduction of social inequality as a result of "the combination of labour market improvements seen by low-skilled workers, including increases in educational attainment and the adoption of increasingly targeted official income policies" (NERI, 2009, p. 222). Although Brazil has increased its budget for Basic Education in recent years, in order to transform the advantages of the market from goods production to sustainable development, the country would have - and still has - a long way to go,

\footnotetext{
${ }^{1}$ It is important to highlight that a definition of IHE should not arise without questioning the process, its origins, as well as the system of inequalities it encompasses. Martinez (2017), for example, challenges the celebratory discourse around the phenomenon by positioning it within the scope of coloniality, according to which a global colonizing process is still in progress as "peripheries are kept in a subordinated position" (p. 38). However, due to the limitations of space in this publication, for the purposes of this paper, it should be enough to claim that mainstream conceptualizations have led the IHE worldwide.
} 
especially in terms of research and development (SCHNEIDER, 2009). Such circumstances suggest the trend by which the integration of countries through globalization affects not only international trade, but also changes "the basis of the world economy from industry to knowledge" (BLOOM, 2004, p. 59).

In this context, the IHE in Brazil was intensified and reconfigured, especially due to the creation of the federal program known as Science without Borders (SwB), from 2011 to 2015. Focusing on technological innovation in priority areas for the country, through public-private partnerships, the initiative offered approximately 100,000 scholarships for outbound mobility, mainly for undergraduate students. The Program's website emphasized that $\mathrm{SwB}$ was conceived through a focus on technology and innovation, and had the enhancement of Brazilian companies' competitiveness among its core aims. ${ }^{2}$

From the unfolding of $\mathrm{SwB}$, specific demands related to the languages required by the IHE surfaced, culminating in the creation of another federal program in 2012: English without Borders (EwB), which emerged as a relatively quick response to the demand for improvement of the English proficiency of Brazilian undergraduate students. The initiative was articulated through three main actions: a) diagnosis of English language proficiency of university students through international tests, b) distance learning through "My English Online (MEO) platform", and c) classroom courses in Language Centers (LC) created at the Federal Universities.

In November 2014, the Program was redesigned in order to cover activities aimed at teachers' education, as well as to include other languages, and was thus renamed Languages without Borders (LwB). However, considering that English continues to be prominent in the governmental initiative, the present study focuses on Languages without Borders - English (LwBE).

Bearing those aspects in mind, this paper is derived from this author's doctoral dissertation, ${ }^{3}$ which explores the English Language Ideologies

\footnotetext{
${ }^{2}$ Source http://www.cienciasemfronteiras.gov.br/web/csf/empresas

${ }^{3}$ Doctoral dissertation entitled "English without Borders program as a language policy: a study on English language ideologies in the context of the internationalization of higher education in Brazil", supervised by professor Telma Gimenez, in the Language Studies Graduate Program, at State University of Londrina.
} 
(ELI) underlying the Federal Program LwBE. To present a comprehensible synthesis of study, in the first section, it presents the data and aspects regarding the use of NVivo 11 software. In the second section, it details the foundations of the Policy Cycle Approach and Critical Discourse Analysis employed in the investigation. In the third section, the analyses of the six ELI investigated in the context of LwBE are presented in order to exemplify their occurrence. To conclude, implications of the program's ratification and English hegemony issues in LP are discussed.

\section{The sets of texts}

According to Ball (1994), policies are conceived as both text and discourse. According to Fairclough, (1995) a text is defined as a linguistic cultural artefact, written or oral, which may also be comprised of other multi-semiotic forms. Considering that textual materiality of a policy derives from efforts and agreements made by different actors engaged in political processes, discourse may be considered a social practice, which does not merely reflect or represent individuals and objects, but dialogically constitutes them (BALL, 1994; FAIRCLOUGH, 1992, 1995). Having said that, in order to analyze the ELI underlying LwBE, this study focuses on three sets of texts, which materialize the enactment of the Program: legal (7 texts), ${ }^{4}$ journalistic (43 texts), ${ }^{5}$ and educational spheres (78 texts). ${ }^{6}$

NVivo 11 software was used to organize the interpretive categories that emerged from the three sets of texts. The use of computer programs for qualitative data analysis has become popular; in language studies

\footnotetext{
${ }^{4}$ Ordinances published by the Ministry of Education, which establish the guidelines for LwBE.

${ }^{5}$ News reports published on three webpages: two news websites of national reach (Folha de São Paulo and Estado de São Paulo) and the official news website of the Ministry of Education (Sala de Imprensa).

${ }^{6}$ Interviews done with the coordinators of ten LCs where LwBE was carried out. In this set, there are also 68 syllabuses/programs of English Language courses offered in the LCs. The coordinators taking part in the study signed a term of informed consent and assent communicating their will to be identified or not in the complete study. However, due to the limitations of space in the publication, it is unfeasible to provide further details about each coordinator and the contexts they are from. For this reason, in this paper efforts are made to keep the anonymity of the coordinators.
} 
especially, software represents a breakthrough in the management of qualitative data due to the complex computational resources they provide. The role played by researchers still remains central, though, as their choices and methodological rigor in the processes of analysis are essential in the construction of qualitative studies' syntheses (MACMILLAN, 2005).

For this study, the coding resources were used as aids in the organizational and analytical processes. To do so, first, three internal folders were created to store the texts according to their respective spheres (legal, journalistic, and educational). Considering that the journalistic sphere has three different sources of texts, sub-folders were created within it (Estado de São Paulo, Folha de São Paulo, and Sala de Imprensa). After, six different categories (or "codes") were created, representing the six ELI analyzed in this study. ${ }^{7}$ Excerpts of the texts identified as belonging to categories were selected and recorded, so that they could later be accessed from different routes organized by the software.

\section{Policy Cycle Approach (PCA) and Critical Discourse Analysis (CDA)}

Considering the dynamic nature of policies, the present analysis of LwBE draws on the foundations from the "Policy Cycle Approach" (PCA), as proposed by Bowe, Ball, and Gold, (1992) and Ball (1994). PCA is a framework which provides tools to support the investigation of different dimensions of a policy's enactment. According to this approach, a public policy is developed in a continuous cycle comprised of three main contexts: context of influence, context of text production, and context of practice.

The context of influence is characterized by social groups that build their discourses in order to sway the drafting of policies toward to their interests. The voices of different actors are present in an asymmetric design; as a result, the legitimized discourses interfere in the construction of the policy. The context of text production represents exactly what its name indicates: it assembles the texts that guide the intended policy, commonly comprised of official documents, such as laws, decrees, and statements. By

\footnotetext{
${ }^{7}$ The analysis arises from the ELI that emerged from the intertextual and interdiscursive interweaving of the data set. The ELI comprising the six interpretative categories of the study had already been inventoried by the literature from the field.
} 
contrast, the context of practice is the environment in which the policies are interpreted and recreated. In the case of an LP, the individuals engaged in educational practices are prominent within the context. Teachers, principals, and coordinators can reject, re-create, or deliberately (or not) misunderstand the policy. The analysis of this dimension implies the recognition that the authors of a policy cannot control its interpretations. These three contexts are not independent in the policy analysis, but rather work in a complementary manner (BOWE; BAL; GOLD, 1992; MAINARDES, 2006).

Despite its focus on the textual and discursive dimensions of policies, PCA does not have its own framework for language analysis, a gap which can possibly be filled by Critical Discourse Analysis (CDA), as several studies have already indicated in the field of LP (RICENTO, 2006B; WODAK, 2006; KRZYZANOWSKI; WODAK, 2011).

CDA is concerned with the use of language in contexts in which power is exercised; it seeks to critically understand how inequalities are established and sustained through language (WODAK, 2001). Inserted in a multi/interdisciplinary field, CDA resorts to the combination of linguistic and social theories to construct analyzes (BLOMMAERT, 2005; KHOSRAVINIK, 2010). It historically emerges from the contributions of Halliday and Matthiessen (2004) through systemic functional linguistics (SFL). Drawing from SFL theory, Fairclough's three-dimensional model of analysis $(1992,2003)$ is considered foundational in the history of CDA. This highlights the relationship between discourse and socially constructed meanings in language (BLOMMAERT, 2005).

PCA and CDA frameworks share common assumptions, such as those provided by Critical Theory, guided by the studies of the Frankfurt school. According to this school of thought, the intellectual must go beyond expressing what is historically necessary for the emancipation of the oppressed. Both approaches favor research that recognizes inequalities and subsidizes transformations in reality (IVES, 2004). Such aspects insert this study in Critical Language Policy (CLP) research paradigm (TOLLEFSON, 2006).

The analysis of social phenomena, such as LP, is a complex task. Thus, as Ball (1994, p. 14) points out, in investigations of this nature, "two theories are probably better than one". That is, the complexity and scope of the study 
require the researcher to use a "toolbox of diverse concepts and theories" (p. 14), which enables analyses. Therefore, the combination of PCA and CDA in the study of LwBE provides possibilities for exploring the relations between research on public policies and language studies.

\subsection{Analytical Framework}

The analysis presented in this paper aims to explore the meanings constructed through the sets of texts which subsidize and materialize LwBE as an LP, focusing on the ELI underlying the federal Program. According to Fairclough (2003), there are three main types of meanings embedded in the orders of discourse, making up the network of social practices in relation to their linguistic dimension, namely actional, identificational, and representational meanings. Actional meaning refers to the genres as tools to act and interact in social practices, concerning actions as social events, as well as actions upon others. Identificational meaning regards styles in ways they identify individuals and social entities, while representational meaning implies representations of the world expressed through discourse (FAIRCLOUGH, 2003). The concept of representation is central to this study, as it is conceived as a process of social construction of practices performed especially through discourses. As such, representations tend to be ideological, since they presuppose worldviews and specific interests (FAIRCLOUGH, 1995, 2003).

CDA's analytical devices allow us to explore textual meanings tied to particular modes of "representing, (inter)acting and identifying the situated social practices” (RAMALHO; RESENDE, 2001, p. 112). The following are the analytical resources employed in this investigation: transitivity; intertextuality; interdiscursivity, evaluation; and metaphors.

\subsubsection{Transitivity}

The analysis of the ways of representing in the set of texts is made in reference to transitivity. Transitivity was initially defined by Halliday and Matthiessen (2004) within SFL as a system which "construes the world of experience into a manageable set of PROCESS TYPES. Each process type provides its own model or schema for construing a particular domain of experience as a figure of a particular kind" (p. 170). 
Transitivity is associated with the ideational function of language which, according to the SFL approach, concerns aspects of a clause or a sentence referring to the ways reality is represented within discourse (FAIRCLOUGH, 1992). Such analysis focuses on the processes (types of verbs), participants (social actors), and circumstances (adverbial phrases), as the choices expressed by each of these elements may be cultural, political, and ideologically meaningful (FAIRCLOUGH, 1992).

The transitivity system consists of a set of six process types (HALLIDAY; MATTHIESSEN, 2004): material processes (processes of doing and happening), mental processes (process of sensing), relational processes (process of being and having), verbal processes (process of saying), behavioral processes (process of behaving), and existential processes (processes of existing).

\subsubsection{Intertextuality and interdiscursivity}

To explore how different ELI emerge in LwBE, the sets of texts representing the Program are analyzed with focus on intertextuality and interdiscursivity, since "any discursive practice is defined by its relations with others, and draws upon others in complex ways" (FAIRCLOUGH, 1992 , p. 55). Intertextuality presupposes that meaning is not built in the void; it is the result of overlapping utterances which embed multiple meanings (JOHNSON, 2015). There are two categories of intertextuality: manifest, regarding explicit verbatim; and constitutive, concerning discursive conventions, that is interdiscursivity (FAIRCLOUGH, 1992; JOHNSON, 2015).

The focus on intertextual and interdiscursive relations allows us to understand how language is articulated in the set of texts that make up LwBE, more specifically how the ELI underpin and are underpinned through the LP, in order to maintain or challenge relations of domination, especially regarding to the role(s) played by English in the IHE in Brazil. 


\subsubsection{Evaluation ${ }^{8}$}

Evaluation belongs to the identificational dimension, as it is initially observable in styles. This dimension regards statements expressing appreciations provided by the speaker, which can be more or less explicit. Evaluative sentences are statements about what is desirable or undesirable from the point of view of the utterer. These are commonly performed in mental processes that denote the affective dimension of the enunciator's analysis (FAIRCLOUGH, 2003; RAMALHO; RESENDE, 2011).

\subsubsection{Metaphors}

A metaphor is conceived as "a conceptual mapping from a semantic source domain to a different semantic target domain" (SANTA ANA, 2002, p. 26), the source domain usually consisting of elements of the physical world that are transferred to more conceptual domains. Metaphors are taken as analysis unities of discursive practices that express the weaving of social relations into language expressions, embodying ideological assumptions of commonplace public discourse (SANTA ANA, 2002).

\section{Language Ideologies under study}

The present study aligns with a critical definition of ideology, that is, it encompasses significant symbolic phenomena which serve, particularly in sociohistorical circumstances, to create and maintain relations of domination between different groups (THOMPSON, 1984). This definition is linked to the focus of this study: Language ideologies (LIs) and English language ideologies (ELIs). LIs express the views users have about such elements as the use, norms, forms, functions, quality, and value of languages (SILVERSTEIN, 1979; WOOLARD, 1998), while ELIs both support or challenge the expansion of English in contemporary times (PAN, 2015). This study resorts to ELIs already identified by previous works from the field in order to analyze the LP embodied by LwBE in the context of IHE in Brazil.

\footnotetext{
${ }^{8}$ In the original study "modality" - defined as commitments that the enunciator assumes in the discourse, especially regarding truth (epistemic) and necessity (deontic) (FAIRCLOUGH, 2003) - was also considered. However, the excerpts presented in this paper do not explore this resource.
} 
From a PCA framework, it was possible to understand that the juxtaposition of the three contexts in which the LP is developed influence, production of texts, and practice - emerged as a major aspect of how LwBE is enacted. Thus, to build a coherent analytical narrative, a presentation organized by ELIs - adopted as interpretive categories in this study - seemed the most appropriate option. As ELIs intertwine, the analysis aimed to explore their interrelation through the three contexts of LP. The following picture shows the colored lines as the woven ELIs that compose the texture of the three circles, each of which represents the contexts of LwBE's enactment.

FIGURE 1 - Woven ELIs composing the texture of the LP's contexts of enactment

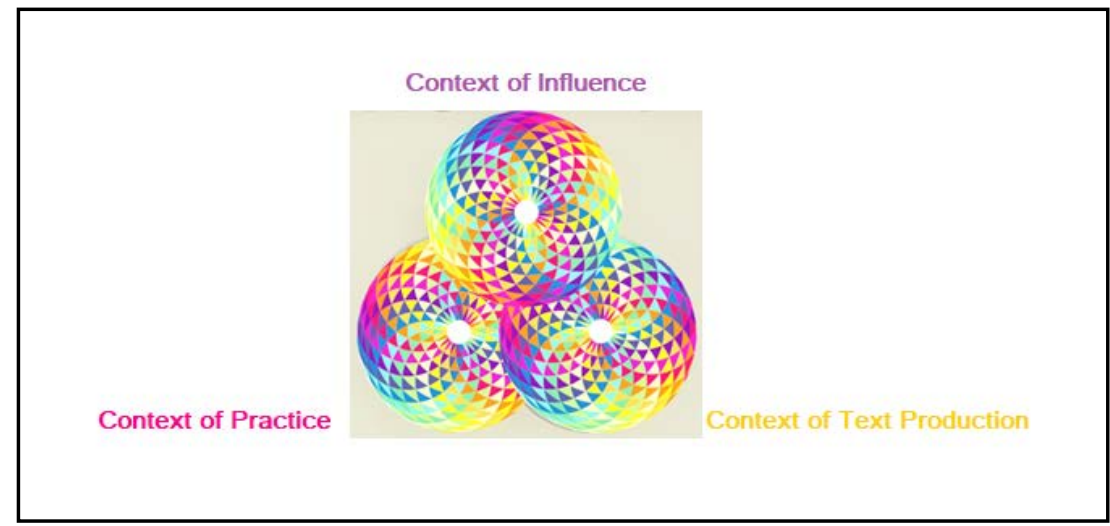

Source: Adapted from Bowe, Ball, and Gold (1992). ${ }^{9}$

\section{English Language Ideologies (ELIs) in LwBE}

In this section, each ELI is briefly defined and then excerpts displaying how they are possibly reinforced and potentially questioned through the enactment of $\mathrm{LwBE}$ are presented. The data is explored in order to illustrate how tensions and contradictions occur within the categories. ${ }^{10}$

\footnotetext{
9 The three circles used in the figure come from the illustration "Torus Yantraou the Hypnotic eye" by VidyaThotangare (ID 493737598, paid license from www.shutterstock. com, in 11/08/2017). Composition of figure 3 by the designer Luís Fernando Martins Rodrigues.

${ }^{10}$ For the full study, see also Passoni (2018).
} 


\subsection{Standard language ideology}

Practices and discourses legitimizing the existence of an ideal linguistic system represent the "standard language ideology". They express a view of languages as synonyms of linearly organized code systems and that are thus capable of standardization. This perspective elevates a linguistic variety to the category of standard, which leads to the imposition of a model that serves as a kind of filter between the individuals who master it and the individuals who do not master it. Considering that it is usually legitimized by formal institutions, such as schools and governments (WOOLARD, 1998; SILVERSTEIN, 1985), it is possible to identify its manifestation within LwBE.

The texts of the three spheres present the actions developed by LwBE, which sought to improve the English language proficiency of university students. The first action, the diagnosis of English language proficiency, stands out in the intertextual and interdiscursive dimensions. In the journalistic sphere, for example, six texts cover the proctoring of TOEFL-ITP (Test of English as a Foreign Language - Institutional Testing Program), as presented in Table 1 below. The emphasis on this strategy points to the circulation of representations linked to the English language in the scope of IHE that tend to emphasize proficiency tests:

TABLE 1 - Thematic cluster from the Journalistic Sphere: news about international proficiency tests

\begin{tabular}{l|l|c}
\hline \multicolumn{1}{c|}{ Publication } & \multicolumn{1}{c}{ Heading } & Date \\
\hline Estado de São Paulo & Exam is also required by English without Borders & $10 / 07 / 2013$ \\
\hline Estado de São Paulo & $\begin{array}{l}\text { MEC will proctor 430,000 English tests at federal } \\
\text { universities }\end{array}$ & $04 / 30 / 2014$ \\
\hline Estado de São Paulo & $\begin{array}{l}\text { Graduate Applicants enjoy the benefit of TOEFL } \\
\text { tests free of charge }\end{array}$ & $06 / 24 / 2014$ \\
\hline Estado de São Paulo & $\begin{array}{l}\text { Proficiency Test will be required by English Without } \\
\text { Borders }\end{array}$ & $04 / 27 / 2015$ \\
\hline Sala de Imprensa & Proficiency tests will be held until June 30 & $05 / 21 / 2014$ \\
\hline Sala de Imprensa & $\begin{array}{l}\text { Test to measure knowledge receives registrations } \\
\text { until November }\end{array}$ & $09 / 16 / 2014$ \\
\hline
\end{tabular}

Source: The author. 
TOEFL-ITP was defined as the best option to cover this strategy, which resulted in the purchase of 500,000 test units. According to LwB's Management Group, the choice was made based on pragmatic accounts. The test was selected because of its uniformity and ability to classify students according to their level of proficiency; its capillarity of application (as it is paper-based, it requires less infrastructure than the online version); its testing of comprehension skills would be sufficient to provide the necessary diagnosis; its focus on proficiency for academic purposes; and, finally, its recognition by most foreign institutions in which students would apply for international mobility (ABREU-E-LIMA; MORAES-FILHO, 2016). Such justifications, however, eventually disregard some ideological implications underlying this choice.

The relationship between proficiency testing and the standard language ideology lies in the fact that these evaluation tools are powerful in determining and perpetuating notions of linguistic correction and standard. The predetermined criteria guiding the test are heavily based on written records from native varieties (SHOHAMY, 2006); thus, non-standard usage is potentially penalized in this process (WOOLARD, 1998; SILVERSTEIN, 1985).

Tests such as TOEFL-ITP set parameters according to standards provided by the Common European Framework (CEF). Although the performance descriptors for the candidates presented at LwBE's webpage are not part of the data analyzed in this study, a glance at its presentation may be relevant to exemplify what Shohamy (2006) defines as a characteristic of proficiency testing, that is, a simplistic view of language. According to the website, the most proficient speaker, C1, is able to understand "difficult and abstract vocabulary in lectures/short academic conversations"; in contrast to the less proficient speaker, A2, who is sometimes able to understand information in "written texts and short dialogs with simple vocabulary." Relational processes define the type of language that C1 and A2 are able to understand (difficult; simple) in a rather superficial and generic manner. Grades or leveling attributed to students by those tests seem to be based on blurred arguments about language proficiency (SHOHAMY, 2006). Moreover, these descriptors tend to rank language learners on scales that position them as having more or less social prestige, as a result of (not) mastering the chosen variety. 
The descriptors are usually guided by a concept of a standard provided by "inner circle" varieties (JENKINS, 2006), a notion that stems from Kachru's Concentric Circles (1989), which organizes English speakers in three groups: inner circle (countries representing native varieties); outer circle (countries where English is the second language, especially ex-British and North-American colonies), and expanding circle (in which the "other" English speakers would be). The risk of oversimplifying the dynamics built between English language and society notwithstanding, Kachru's (1989) representation is indicative of perceptions, thereby establishing a hierarchy among English speakers, which legitimizes those in the center and positions all who are outside of the center in a subaltern condition.

Despite being called international, English proficiency tests, such as TOEFL-ITP, tend to set their parameters according to UK and US standards, ignoring empirical evidence of language use provided by interaction in international contexts (JENKINS, 2006). What seems to prevail is a supposed grammatical correctness and appropriate pronunciation.

However, previous analyses have shown that focus on proficiency tests was most strongly observed on the initial phase of LwBE. Over the years, the objectives of LP seem to go over a process of reformulation. One LC coordinator points out the following:

EXCERPT1<Educational Sphere: Interview with LC coordinator $1>$

At first, the courses were totally geared towards the TOEFL test. So it was very, very, very specific; our courses were really targeted, hence the development of specific skills for the test, oral skills, written skills. I had a specific TOEFL preparation course. [...] As the profile of the students changed, we were also adapting our courses to this new profile. In fact, students are no longer interested in taking the TOEFL test. [...] So we offer a TOEFL prep class and sometimes this course is not even offered. And we were then checking what the students wanted and then we offered it. We now offer, for example, teaching English through movies and songs. It is a course that has an immense demand because we can approach a multitude of themes working with music and movies, current themes, more comprehensive themes. We then work with intercultural issues, with various things. [...] Although it is not the students' will, so to speak, to take the TOEFL test. The academic writing course is also.... Then we can have one course like this in each course offer too, not more than that. 
Verbs in the past tense denote program updates (relational: were, was; existential: had), especially because the characteristics of the students (participants: students profile, material process: changed) also changed (material process: we are also adapting our courses). Coordinator 1's comments indicate that taking the proficiency test is not a priority for the new profile of students (relational process: students are no longer interested; behavioral process: it is not the students' will), which affects the low demand for courses for this purpose (circumstances: sometimes, existential process: this course is not even offered). Currently, the courses focus on aspects other than those emphasized in the preparatory classes for the proficiency tests (circumstances: through films and music; material process: we work with intercultural issues).

Remarks, such as those made by Coordinator 1, point to the diversification of courses offered by the LCs as ways of reacting to the standard language ideology underlying the emphasis given to the proctoring of the proficiency tests. Five of the ten coordinators provided lists of the courses offered by LwBE at their universities at the time of their interview. From a total of 68 listed courses, 14 mention the preparation for proficiency tests. Therefore, it is possible to recognize the diversity languages courses held at the LCs as an emerging answer to the standard language ideology, which potentially derives from the local appropriations of the LP.

\subsection{English language as a commodity ideology}

In a globalized economic system, English has become a valuable exchange resource. The "English Language as commodity ideology" embraces this perspective and can be acknowledged in different economic activities, such as tourism, translation services, communications, arts, and, more importantly to this study, language teaching (HELLER, 2010).

Yet under the influence of the industrial age, the new economy is marked by the Taylorist model of standardization and the production line that sought to maximize production and profits. "Linguistic Taylorism" (HELLER; DUCHÊNE, 2012) emerges from this context, a logic that transposes the regulation model employed for physical and mechanical work within the "language industries", or more specifically to this study, the "English industry" (GRAY, 2012). The English industry can be defined 
by three overlapping dimensions: commercial English teaching, English language tests, and academic publications in English.

The sets of texts that materialize LwBE express the presence of the "English language as a commodity ideology" through representations that indicate the tendency to conceive the language as a product and/or as services linked to it (SZUNDY, 2016), as expressed in the news about the Program:

EXCERPT $2<$ Journalistic Sphere - Sala de Imprensa10: Capes President presents data from the CsF in a seminar related to the area of health $>$

With the aim of developing English language fluency as a preparation for applications to Science without Borders, the Capes President highlighted the English without Borders program, which gives students the opportunity to study the language free of charge, in online courses, My English Online was developed by the educational sector of National Geographic Learning, in partnership with Cengage Learning, as well as in classroom courses.

EXCERPT 3<Journalistic Sphere - Estadão17: Graduate Applicants enjoy the benefit of TOEFL tests free of charge>

Graduate Applicants enjoy the benefit of TOEFL tests free of charge

The excerpts above indicate both the language courses and the provision of proficiency tests (circumstances: free of charge) as actions sponsored by LwBE. Such an emphasis denotes two relevant aspects: on the one hand, the students do not need to pay for the courses or the tests promoted by the Program; on the other hand, in the English industry, the tests and lessons will certainly be paid, mainly by public-private partnerships.

The private sector has traditionally been dominant as a provider of English language courses and proficiency tests. In Brazil, the powerful role played by private language institutes ${ }^{11}$ has corroborated the "English as a commodity ideology", which highlights the (im)possibilities of learning the language in the country, and consequently, the opportunities arising or

\footnotetext{
${ }^{11}$ To illustrate, it could be mentioned that according to the Brazilian Association of Franchising (ABF) website, from the 99 registered education providers, virtually half, 48 enterprises, offer some kind of English language course. Source: https://www.abf.com. br/a-abf/franquias-associadas-abf/.
} 
diminishing from it. Emphasising courses and tests for free within LwBE distinguishes the federal initiative from other providers. In the excerpt below, Coordinator 2's accounts show how students' income has hitherto determined their prospects of learning the language, and thus of engaging in the IHE.

\section{EXCERPT $4<$ Educational Sphere: interview with LC coordinator $2>$}

Their needs are those of who studied English in high school in a public institution, ${ }^{12}$ a large majority, who did not have a parallel or private language course in their education process due to economic reasons, so they come with a rather large language deficiency in English, which discourages them, for example, from attempting the exchange program opportunities [...]

Coordinator 2 describes the needs of the students engaged in the activities promoted by $\mathrm{LwBE}$ (relational process: a rather large language deficiency in English), associating the lack of English proficiency to the discrediting of public education (circumstance: English in high school in public institution) and the financial situation of students from this context (circumstances: due to economic reasons). According to her, these limitations create obstacles for students to take part in the mobility programs (behavioral process: discourage them).

By the analysis presented above, it is possible to affirm that the "English as a commodity ideology" underlies the enactment of LwBE through tensions which pose language as goods or services; however, the providing of courses and free-of-charge tests allows for the possibility of challenging such an ideological construction in IHE in Brazil.

\subsection{Native-speakerism ideology ${ }^{13}$}

Despite the evident deterritorialization of the English language in contemporary times (BLOMMAERT, 2010), the valuing of the native speaker is still a strong influence in English language teaching and learning.

\footnotetext{
12 The analysis stems from Coordinator 2's comments on the issue. There is no research evidence about the context where LwBE students could have studied English language prior or during their time at the Program.

${ }^{13}$ Preliminary findings from this category were published in Passoni (2017).
} 
Holliday (2015) uses the term "native-speakerism" to refer to the ideology which promotes the ideal of the native speaker as a superior model, especially in the area of English teaching, by emphasizing such aspects as accent, teaching methodologies developed by Western institutions, and the predominance of the language in internationally renowned publications.

Several strategies and partnerships held by LwBE pose native speakers and their countries - especially the United States of America - as legitimate sources for English teaching, as the intertextual and interdiscursive analysis of the journalistic sphere suggests. For instance, according to table 2, five texts present the aids received by the Program: the donation of language laboratories by American companies, regarding the physical infrastructure; and the work of American assistant teachers, concerning the staff involved in the Program.

TABLE 2 - Thematic cluster from the Journalistic Sphere:

News about the support offered to LwBE

\begin{tabular}{c|l|c}
\hline \multicolumn{1}{c|}{ News Website } & \multicolumn{1}{|c}{ Heading } & Date \\
\hline Estado de São Paulo & $\begin{array}{l}\text { English without Borders will have laboratories donated by } \\
\text { American companies }\end{array}$ & $11 / 13 / 2013$ \\
\hline Estado de São Paulo & $\begin{array}{l}\text { Federal universities to receive English language } \\
\text { laboratories in 2015 }\end{array}$ & $11 / 16 / 2013$ \\
\hline Sala de Imprensa & $\begin{array}{l}\text { English Language Assistant Teaching Program } \\
\text { Scholarship holders will work at English without } \\
\text { Borders }\end{array}$ & $08 / 15 / 2013$ \\
\hline Sala de Imprensa & $\begin{array}{l}\text { Teachers who will teach at English Learners } \\
\text { without Borders are hosted by Capes }\end{array}$ & $02 / 17 / 2014$ \\
\hline Sala de Imprensa & $\begin{array}{l}\text { American teachers participate in orientation } \\
\text { seminar }\end{array}$ & $02 / 19 / 2015$ \\
\hline
\end{tabular}

Source: The author. 
In addition to the role played by those providers, some aspects of the course syllabi portray how American culture and varieties of English are deemed important for teaching and learning at the LCs.

EXCERPT $5<$ Educational Sphere - Course name: Intercultural communication in English Language: "phrasal verbs", idiomatic expressions and slangs

Course syllabus: A study on phrasal verbs, focusing on the 25 most common phrasal verbs in the English language, idiomatic expressions and useful slangs for intercultural communication. Emphasis on oral and spontaneous use of new phrases in discussions and conversation activities.

The course syllabus above aims to teach phraseological units, that is, fixed expressions that are repeated in pre-established patterns (phrasal verbs, idioms, and slangs). As those structures tend to be shaped by the cultural load they carry, they can relate English language proficiency to nativeness (PRODROMOU, 2003). It also highlights these expressions as convenient for (relational process: useful) interaction between different cultures in English (circumstance: for intercultural communication in English). Although it presents no further details regarding the methodology, it is possible to acknowledge that "native-speakerism ideology" underlies the course program, as it focuses on aspects that mark the authenticity of the native speaker in communication; therefore, it tends to assume that either one should learn English specifically to interact with native speakers of a certain variety or one should perform that model as language user (SEIDLHOFER, 2011).

However, other course syllabi and situated actions at LCs depict the possibilities of questioning such an ideological construction in English language teaching and learning, aimed at intercultural communication in a broader sense. Local appropriations of LP have the potential to challenge the perspective that defines intercultural communication as a "one-way street" (KRAMSCH, 2001, p. 205), according to which teaching English traditionally meant transmitting information from English speaking countries coupled with the behaviors of native speakers. 
EXCERPT 6<Educational Sphere: Interview with LC coordinator $1>$

So for example, we prepared short courses of 16 hours, two courses that we offer ... is "Getting to Know [NAME OF A CITY]". Then getting to know the city of [NAME OF A CITY] in English. The course was a success. We had about 70 students on the waiting list. And it was really, really interesting. Doing all this work of going out, knowing, researching the history of the place. So they loved it, the students are not from [NAME OF A CITY], they come from different parts of Brazil. They loved to know the city and do all this work, all this knowledge in the English language. They felt really good that the ETAs helped, they strolled, so we walked the streets of [NAME OF A CITY] talking in English and getting to know our culture. It was really interesting.

In the excerpt above, Coordinator 1 talks about the course called "Getting to Know [NAME OF A CITY]", which aimed to learn the English language through activities that explored the places and the culture of the city (material process: going out, strolled, walked; mental process: knowing, researching; oral process: talking). The coordinator reports positive evaluations, both on her part (very interesting) and her perception of students (mental process: loved; behavioral process: they felt really good). In her experience, the native speakers (social actors: ETAs - English Language Assistants) worked as assistants in this process, not as the main authorities from whom the knowledge would come (material process: helped). Considering the goal of the course, the ETAs could also take the opportunity to learn about the city where they were living at that moment.

\subsection{Instrumentalist ideology}

The "instrumentalist ideology" assumes languages are tied to their value associated with development, modernization, and economic advancement. In this perspective, English is taken as a tool for economic, commercial, technological, and cultural exchanges within globalization (SEARGEANT, 2009; PAN, 2015). It relates to Bourdieu and Passeron's (1977) discussion about "linguistic capital", which assumes language converts into other forms of capital, becoming valuable "to the extent that it helps us achieve goals and objectives that we value" (ROBICHAUD, DE SCHUTTER, 2012, p. 124). Thus, languages that are potentially spoken by 
a group of people as broad as possible should be fostered (ROBICHAUD; DE SCHUT'TER, 2012).

Languages emerge as auxiliary tools which support the IHE, since teaching them was not a main goal when SwB was created. LC Coordinator 3 acknowledges this representation in his accounts:

EXCERPT 7<Educational Sphere: Interview with LC coordinator 3>

Today, Science without Borders is subordinate to the Ministry of Science and Technology, and Languages without Borders is subordinated to the Ministry of Education with the Secretariat of Higher Education, SeSu. Nowadays, these programs are totally separated, independent, but one was born from the other. In fact, LwB came to linguistically instrumentalize SwB candidates who would go abroad.

The current situation of LwBE (circumstance: today) indicates an autonomous characterization of the LP in the scope of IHE (relational processes: they are totally separated, independent). However, in indicating the origin of the Program through the metaphor of birth (material process: one born of the other), it is possible to say that for Coordinator 3 , the language teaching offered by LwBE is the "child" of the international mobility provided by SwB. That is, instead of languages enabling mobility, it was precisely the absence of them in SwB which motivated the creation of the LwBE (material process: came to linguistically instrumentalize SwB candidates). In this sense, the "instrumentalist ideology" underlies the LP, as the languages promoted by LwBE are the means by which international mobility would be reached (circumstance: abroad).

Nonetheless, along with the development of the LP, local appropriations created possibilities for deconstructing such an ideology. The expansion of the courses' scope at the LCs point to possible redefinitions of the role played by English in the IHE: 
EXCERPT $8<$ Educational Sphere: Interview with LC Coordinator 1>

In the beginning there was a specific goal of participating in the Science without Borders program. But it's been a long time, a year, a year and a half, more....that their goal is simply to improve English itself. To develop the English language, with no specific purpose of going on exchange.

By signalling the difference between the initial stage of implementation of LwB (circumstances: at the beginning, relational process: was), Coordinator 1 highlights that the preparation for $\mathrm{SwB}$ is no longer central. In describing the current objective of the students who attend the courses (relational process: their goal is simply to improve English itself), Coordinator 1 points to a broader view of language learning, so that their interests go beyond one's preparation for international mobility (relational process: no specific purpose, material process: going on exchange).

Due to the changes supported by the redesigning of LwBE and the local interpretations of the LP, the "instrumentalist ideology" can be challenged in such a way that English can be taken as a complex heuristic artifact that enables communication and interaction among diverse peoples from different cultures (SEARGEANT, 2009).

\subsection{Global language ideology}

The concept of "Global language ideology" is based on two fundamental premises: a) English has spread widely around the world. It is estimated that about 1,500 million people speak English, of which only 375 million would be native speakers; b) In the broad context of globalization, it would be desirable to share a single language which would allow unrestricted communication among people for different purposes (CRYSTAL, 2003; SEARGEANT, 2009). In this perspective, the inclusive adjective "global" emphasizes a homogenizing and universalizing conception of language that, ideologically, tends to erase the hybridizations which emerge from English deterritorialization.

Global language ideology, therefore, seems to underlie the LwBE enactment, especially by relational processes characterizing the language in the scope of the IHE in Brazil. 
EXCERPT $9<$ Journalistic Sphere: Sala de Imprensa4 - Students from public universities will receive a language enhancement program $>$

The Education Minister, Aloizio Mercadante, always emphasizes the importance of teaching languages, especially English. "English has established itself as the language of international sciences ...."

EXCERPT 10<Educational Sphere: Interview with, LC coordinator 4>

I think one of the main issues is that we can have the English language for global communication purposes [...] during the classes we try to make it very clear that the student needs English for the world [...]

EXCERPT 11<Educational Sphere: Interview with LC coordinator 5>

I think this is always an issue, because we usually have students who are familiar with certain language registers, some speak American English and British English, but what we try to deconstruct and tell them is that English, nowadays, is a universal language.

In excerpt 9, the Education Minister, Aloizio Mercadante, defines English as the language of international sciences, emphasizing it as fundamental in the IHE (material process: consolidated). Ideologically, it is sustained by and underpins the "global language ideology", according to which "the dominant view is certainly that a person is more likely to be in touch with the latest thinking and research in a subject by learning English than by learning any other language" (CRYSTAL, 2003, p. 111).

The relational processes in the following excerpts (for global communication; is a universal language) tend to reinforce this ideology through the naturalization of the dominance of English (PHILLIPSON, 2000). Moreover, these representations conceive the language as a single variety, as in Coordinator 5's accounts by which it can be assumed that the questioning he mentions (material process: deconstruct) indicates the existence of a universal variety of the language that would assimilate differences (relational processes: American English and British English), erasing the variations that emerge from the diverse contexts of language use (RAJAGOPALAN, 2012), pointing to a monolingual conceptualization of English, by which language and nation compose a unity (BLACKLEDGE, 2000; WILEY, 2000). 
However, local interpretations of $\mathrm{LwBE}$ also pinpoint possibilities for recognizing the complexity of the deterritorialization of English, which embraces heterogeneity as one of its main traits.

\section{EXCERPT 12<Educational Sphere: Interview with LC coordinator 1>}

It's something we've been studying, reading read about. That there is not only one type of English, one specific language, there is English as a lingua franca, the English of each country. This is something that we discuss...

Coordinator 1's accounts can be seen as challenging the "global language ideology" firstly by characterizing the language in a relational process as "lingua franca". The coordinator does not explicitly define what she means by that term, however, her comments recognize (mental processes: studying, reading) the diversity of English as an emerging aspect in contemporaneity (existential process: there is not only one type of English). Despite associating the language to different countries (relational process: from each country), which could link her considerations to a monolingual orientation of English, Coordinator 1 does not mention nationalities; therefore, it is possible to understand that she refers to language varieties beyond the native standards.

The comments analyzed above indicate the existence of local interpretations of $\mathrm{LwBE}$, which possibly challenge consolidated ideologies. By bringing up considerations about English as a lingua franca (ELF), Coordinator 1 puts to the fore reflections on uses, functions, and contexts, in which English is the means of interaction between speakers who are predominantly non-native, people who have English as an available tool for communication in international and intercultural contexts (SEIDLHOFER, 2011; JENKINS, 2006, 2009). ELF offers a distinctive view of English in the sense that that English is defined as nobody's mother tongue (JORDÃO, 2014), implying the recognition that its diffusion began through conquest and colonization processes, continuing to spread worldwide due to several individual interests in learning English as an addition to their first languages, having diversity is one of its main characteristics (SEIDLHOFER, 2004, 2011). 


\subsection{Linguistic imperialism ideology}

The "linguistic imperialism ideology" considers that the English language is diffused and sustained through processes which are based on structural (material resources) and cultural inequalities (immaterial resources), placing it in a hierarchically superior position in relation to other languages. This proposition arises mainly from Phillipson's studies (1992), who proposed four complementary principles - or fallacies guiding such an ideology: a) English is best taught in a monolingual approach; b) the ideal teacher of English is the native speaker; c) the sooner English is taught, the better the results; and d) if other languages are widely used, English standards will drop.

Concerning its articulation with the monolingual orientation, the assumption that "languages are in competition" (WILEY, 2000, p. 67) is at its core. In this respect, some characteristics of the LP contrasts the role played by English and other languages in LwB.

\section{EXCERPT $13<$ Educational Sphere: Interview with LC Coordinator 3>}

[...] we have been trying to raise awareness in the academic community about the importance of the English language because there are many radical views towards English, "no, it is the language of the Yankees, no, [NAME OF A UNIVERSITY] is Latin America ..." This issue is delicate here at [NAME OF A UNIVERSITY], it is even very specific. So I've already had, for example, I've already received a message from international relations students, for example, "Why is it English? Not another language?" We have to try to explain "look, English, because English was the first language to be developed in the program "[...] And try to explain. It is improving, there are still a lot of barriers to English, but it is already improving. [...]No... the presence of English at [NAME OF A UNIVERSITY] will not exclude Spanish, nor Portuguese, or the indigenous languages, we will add English to [NAME OF A UNIVERSITY]. Bilingualism continues, Portuguese, Spanish, indigenous languages continue, but English is also important. Raising awareness about these issues is not easy, but it is working well in a short time[...] We are disseminating the news about TOEFL, about the LC, and they are beginning to accept, and then the students begin to enroll in the course, they like it and then they call their colleagues and the one who was a little resistant starts to go and sees that it is not quite like that. That English is not only the language of the colonizer and the colonized also speaks English, so we have to explain it all. That's it, it's deconstruction. 
Addressing the implementation of the LP at a Brazilian Federal university, Coordinator 3 reports some resistance from the local community towards English (existential process: there are many radical views towards English, there are still a lot of barriers to English), reactions justified by characteristics of the local context (relational process: [NAME OF A UNIVERSITY] is Latin American; this issue is delicate, circumstances: here at [NAME OF A UNIVERSITY]). The manifestations reported by Coordinator 3 point to resistance from the university community to the "linguistic imperialism ideology" associated to English, as exemplified by questions about the primacy of English in the Program (existential process: "Why is it English? Not another language?"), as well as comments problematizing the origin of the language (relational process: it is the language of the Yankees), also alluding to "native-speakerism". Coordinator 3's reaction to resistances seems to envisage a change of behavior (behavioral process: we have been trying to raise awareness in the academic community; they are beginning to accept). From the coordinator's remarks it is possible to understand that the activities developed by LwBE aim to re-signify the hegemony of English, aimed at different appropriations of the language (behavioral process: It's deconstruction).

Coordinator 3's considerations challenge the "linguistic imperialism ideology" by highlighting the possibility of the coexistence of different languages (existential process: the presence of English at [NAME OF A UNIVERSITY] will not take Spanish, nor Portuguese, or the indigenous languages; material process: we will add English to [NAME OF A UNIVERSITY]; relational process: English is also important).

However, the coordinator's accounts are representative of the contradictions regarding the hegemony of English. While attempting to challenge the supremacy of the language, Coordinator 3 defines English by not denying its colonial roots (relational process: English is not only the language of the colonizer). While arguing language is a resource available to any speaker - regardless of the fact that it could have been imposed - (relational process: who is colonized), the coordinator tends to define English as beneficial, since it offers speakers possibilities of acting (verbal process: also speaks English). Such considerations indicate that, despite the local resistance, what seems to prevail is the universalizing and inclusive sense of the global diffusion of English according to which, 
apparently, "colonizer" and "colonized", as social actors, would enjoy the same conditions and benefits arising from speaking it.

The redesigning of the LP, which included other languages in the Program, could be mentioned as possibly challenging the "linguistic imperialism ideology". Nonetheless, currently, from the 70 universities where LwB is enacted, ${ }^{14}$ only a few of them offer courses or tests in other languages, more specifically: French in 17 institutions, Spanish in 20 institutions, Italian in 7 institutions, German in 20 institutions, Japanese in 5 institutions; and there is no official information about Portuguese for speakers of other languages.

\section{Conclusion}

The concise version of the study presented in this paper argues that LwBE is an LP permeated by six ELIs - standard language, language as a commodity, native-speakerism, global language, instrumentalist, and linguistic imperialism - which converge in the tendency to position English as hegemonic in IHE in Brazil. The overlapping of the six ELIs indicates greater permeability in the contexts of practice in which the LP is interpreted and potentially questioned, while they present greater uniformity in the contexts of influence and production of texts, in which more consistency is observed in the intertwining of the ideologies sustaining English hegemony.

As this study is situated in the CLP paradigm, it aimed to investigate how inequality systems are supported by ideological discourses. By exploring ELIs underlying LwBE, this research addresses how certain representations, or indexicalities (CANAGARAJAH, 2013), are linked to languages and how they embrace values and meanings produced throughout dialogical, historical, and social processes. Therefore, considering that ideologies are not "set in stone" (p. 36), the study of ELIs in LwBE sought to explain how these are subject to questioning and deconstruction, as well as demonstrated that ideologies are not totally fluid or arbitrary (CANAGARAJAH, 2013).

The implications arising from the identified scenario are related to the maintenance of inequalities that, in the case of the IHE, may have different consequences. First, the increased use of English as the main language of the scientific milieu can corroborate benefits to already established academic

\footnotetext{
${ }^{14}$ Source: http:/ /isf.mec.gov.br/, retrieved in May 2018. This paper does not cover LwB's updates after the time of data collection.
} 
systems, which are mostly located in English-speaking countries that, in turn, dominate the educational world system (ALTBACH, 2013). In this regard, the LwBE reformulation to include other languages creates possibilities for scientific production to challenge the English monopoly.

Moreover, by establishing English as the global "monolanguage" of internationalization, the identified ELIs are prone to foster native varieties of English, rather than recognize the hybridisms emerging from the deterritorialization of the language. Thus, IHE potentially promotes structures of inequality that privilege products and services from native English-speaking countries, and these models tend to foster feelings of inadequacy and inauthenticity both from teachers and learners (BERNAT, 2008). Yet, placing non-native speakers as illegitimate users of English is seen as a contradiction, given that, today, they outnumber native-speakers.

If we agree that Brazil is in the race for the IHE aimed at higher quality education and research, as well as enhancements in institutional prestige, the generation of investments, and contributions to local and global development (JONES, 2013), in a critical perspective, such a process must focus on overcoming social contradictions, which implies changes in the consolidated systems of inequality. Therefore, the present study indicates that destabilizing the ELI underlying LwBE would be a desirable endeavor, as the democratization of access to English learning seems to be strengthened in this effort.

\section{References}

ABREU-E-LIMA, D. M.; MORAES-FILHO, W. B. O Programa Idiomas sem Fronteiras. In: ABREU-E-LIMA, D. M.; MORAES-FILHO, W. B.; SARMENTO, S. (Org.). Do Inglês sem fronteiras aos idiomas sem fronteiras: a construção de uma política linguística para a internacionalização. Belo Horizonte: Ed. da UFMG, 2016. p. 293-308.

ALTBACH, P. G. Globalization and the University: Realities in an Unequal World. In: ALTBACH, P. G.; FOREST, J. J. F. (Ed.). International Handbook of Higher Education. Dordrecht: Springer, 2006. p. 121-140. Doi: https://doi. org/10.1007/978-1-4020-4012-2_8

ALTBACH, P. G. The International Imperative on Higher Education. Rotterdam: Sense, 2013. Doi: https://doi.org/10.1007/978-84-6209-338-6

BALL, S. J. Education Reform: A Critical and Post-Structural Approach. Buckinghan: Open University Press, 1994. 
BERNAT, E. Towards Pedagogy of Empowerment: The Case of "Impostor Syndrome" Among Pre-Service Non-Native Speaker Teachers in TESOL. ELTED, Fremantle, v. 11, p. 1-8, 2008.

BIZON, A. C. C. Narrando o exame Celpe-Bras e o convênio PEC-G: a construção de territorialidades em tempos de internacionalização. 2013. 445 f. Dissertation (Ph.D. in Applied Linguistics) - Universidade de Campinas, Campinas, 2013. Doi: https://doi.org/10.21879/ faeeba2358-0194.v23.n41.861

BLACKLEDGE, A. Monolingual Ideologies in Multilingual States: Language, Hegemony and Social Justice in Western Liberal Democracies. Estudios de Sociolingüística, Ciudad de México, v. 1, n. 2, p. 25-45, 2000. Doi: Doi: https://doi. org/10.1558/sols.v1i2.25

BLOMMAERT, J. Discourse: A Critical Introduction. Cambridge: Cambridge University Press, 2005. Doi: Doi: https://doi.org/10.1558/sols.v1i2.25

BLOMMAERT, J. The Sociolinguistics of Globalization. Cambridge: Cambridge University Press, 2010. Doi: https://doi.org/10.1017/CBO9780511845307

BLOOM, D. E. Globalization and Education: an Economical Perspective. In: SUÁREZ-OROZCO, M. M.; QIN-HILLIARD, D. B. (ed.). Globalization: Culture and Education in the New Millennium. California: University of California Press, 2004. p. 56-77.

BOURDIEU, P.; PASSERON, J. Reproduction in Education, Society and Culture. California: Sage, 1977.

BOWE, R.; BALL, S. J.; GOLD, A. Reforming Education \& Changing Schools: Case Studies in Policy Sociology. London: Routledge, 1992.

CANAGARAJAH, A. S. Translingual Practice: global Englishes and cosmopolitan relations. New York: Routledge, 2013. Doi: https://doi.org/10.4324/9780203120293 CRYSTAL, D. English as a Global Language. Cambridge: Cambridge University Press, 2003.

FAIRCLOUGH, N. Analysing Discourse: Textual Analysis for Social Research. London: Routledge, 2003. Doi: https://doi.org/10.4324/9780203697078

FAIRCLOUGH, N. Critical Discourse Analysis as a Method in Social Scientic Research. In: WODAK, R.; MEYER, M. Methods of critical discourse analysis. London: Sage, 2001. p. 121-138. Doi: https://doi.org/10.4135/9780857028020.n6

FAIRCLOUGH, N. Critical Discourse Analysis. London: Longman, 1995.

FAIRCLOUGH, N. Discourse and Social Change. Cambridge: Polity Press, 1992.

GRAY, J. English the Industry. In: HEWINGS, A.; TAGG, C. (ed.). The Politics of English: Conflict, Competition, and Co-Existence. Milton Keynes: The Open University Press, Routledge, 2012. p. 137-163. 
HALLIDAY, M. A. K.; MATTHIESSEN, C. M. I. M. An Introduction to Functional Grammar. 3. Ed. New York: Oxford University Press, 2004.

HELLER, M. The Commodification of Language. Annual Review of Anthropology, Palo Alto, v. 39, p. 101-114, 2010. Doi: https://doi.org/10.1146/annurev. anthro.012809.104951

HELLER, M.; DUCHÊNE, A. Pride and Profit: Changing Discourses of Language, Capital and Nation State. In: HELLER, M.; DUCHÊNE, A. Language in Late Capitalism: Pride and Profit. London: Routledge, 2012. Doi: https://doi. org/10.4324/9780203155868

HOLLIDAY, A. Native-Speakerism: Taking the Concept Forward and Achieving Cultural Belief. In: SWAN, A.; ABOSHIHA, P.; HOLLIDAY, A. (ed.). (En)countering Native-Speakerism: Global Perspectives. Basingstoke: Palgrave Macmillan, 2015. p. 11-25. Doi: https://doi.org/10.1057/9781137463500_2

IVES, P. Gramsci's Politics of Language: Engaging the Bakhtin Circle \& the Frankfurt School. Toronto: University of Toronto Press, 2004. Doi: https://doi. org/10.3138/9781442675490

JENKINS, J. The Spread of EIL: A Testing Time for Testers. ELT Journal, London, v. 60, n. 1, p. 42-50, 2006. Doi: https://doi.org/10.1093/elt/cci080

JENKINS, J. World Englishes. 2. ed. London: Routledge, 2009.

JOHNSON, D. C. Intertextuality and Language. In:JOHNSON, D. C.; HULT, F. M. (ed.). Research Methods in Language Policy and Planning: A Practical Guide. Oxford: W. Blackwell, 2015. p. 166-180. Doi: https://doi.org/10.1002/9781118340349.ch15 JONES, E. Internationalization and Employability: The Role of Intercultural Experiences in the Development of Transferable Skills. Public Money \& Management, Edinburgh, v. 33, n. 2, p. 95-104, 2013. Doi: https://doi.org/10.1080/09540962 .2013 .763416

JORDÃO, C. M. ILA, ILF, ILE, ILG: quem dá conta? Revista Brasileira de Linguistica Aplicada, Belo Horizonte, v. 14, n. 1, p. 13-40, 2014. Doi: https://doi.org/10.1590/ S1984-63982014000100002

KACHRU, B. B. World Englishes and Applied Linguistics. Studies in the Linguistics Sciences. Illinois Working Papers, Champaign, v. 19, n. 1, p. 127-52, 1989.

KHOSRAVINIK, M. Actor Descriptions, Action Attributions, and Argumentation: Towards a Systematization of CDA Analytical Categories in the Representation of Social Groups. Critical Discourse Studies, Abingdon, v. 7, n. 1, p. 55-72, Feb. 2010. Doi: https://doi.org/10.1080/17405900903453948 
KNIGHT, J. Internationalization Remodeled: Definitions, Rationales, and Approaches. Journal of Studies in International Education, Amsterdam, v. 8, n. 1, p. 5-31, 2004. Doi: https://doi.org/10.1177/1028315303260832

KRAMSCH, C. Intercultural Communication. In: CARTER, R.; NUNAN, D. (ed.). The Cambridge Guide to teaching English Speakers of Other Languages. Cambridge: CUP, 2001. p. 201-206. Doi: https://doi.org/10.1017/CBO9780511667206.030

KRZYZANOWSKI, M.; WODAK, R. Political Strategies and Language Policies: The European Union Lisbon Strategy and its Implications for the EU's Language and Multilingualism Policy. Lang Policy, Dordrecht, v. 10, n.2, p. 115-136, 2011. Doi: https://doi.org/10.1007/s10993-011-9196-5

MACMILLAN, K. More Than Just Coding? Evaluating CAQDAS in a Discourse Analysis of News Texts. Forum: Qualitative Social Research, Berlin, v. 6, n. 3, Art. 25, p. 1-18, Sept. 2005.

MAINARDES, J. Abordagem do Ciclo de Políticas: uma contribuição para a análise de políticas educacionais. Educaşão \& Sociedade, Campinas, v. 27, n. 94, p. 47-69, Jan./ Apr. 2006. Doi: https://doi.org/10.1590/S0101-73302006000100003

MARTINEZ, J. Z. Entre fios, pistas e rastros: os sentidos emaranhados da internacionalização da Educação Superior. 2017. 213f. Dissertation. (Ph.D. in Letters) - Faculdade de Filosofia, Letras e Ciências Humanas, Universidade de São Paulo, São Paulo, 2017.

MOROSINI, M. C. Estado do conhecimento sobre internacionalização da educação superior: conceitos e práticas. Educar, Curitiba, v. 22, n. 28, p. 107-124, 2006. Doi: https://doi.org/10.1590/S0104-40602006000200008

NERI, M. Income Policies, Income Distribution, and the Distribution of Opportunities in Brazil. In: BRAINARD, L.; MARTINEZ-DIAZ, L. (Ed.). Brazil as an Economic Superpower? Understanding Brazil's Changing Role in the Global Economy. Washington: Booking Institution Press, 2009. p. 221-270.

PAN, L. Deconstructing the Ideological Discourses of English in Language Education. London: Springer, 2015.

PASSONI, T. P. Native-Speakerism and English Without Borders Program: Investigating Language Ideologies Through a Language Policy. Brazilian English Language Teaching Journal. Porto Alegre, v. 8, n. 1, p. 40-59, 2017. Doi: https:/ /doi. org/10.15448/2178-3640.2017.1.26842

PASSONI, T. P. O Programa Inglês sem Fronteiras como política linguística: um estudo sobre as ideologias da língua inglesa no âmbito da internacionalização do ensino superior brasileiro. 2018. 278f. Dissertation (Ph.D. in Language Studies) Universidade Estadual de Londrina, Londrina, 2018. 
PHILLIPSON, R. Linguistic Imperialism. New York: Oxford University Press, 1992. PHILLIPSON, R. English in the New World Order: Variations on a Theme of Linguistic Imperialism and "World English". In: RICENTO, T. (Ed.). Ideology, Politics and Language Policies: Focus on English. Amsterdam: J. Benjamins, 2000. p. 87-106. Doi: https://doi.org/10.1075/impact.6.08phi

PRODROMOU, L. Idiomaticity and the Non-Native Speaker. English Today: The International Review of the English Language, Cambridge, v. 74, n. 2, p. 42-48, 2003. Doi: https://doi.org/10.1017/S0266078403002086

RAJAGOPALAN, K. 'World English' or 'World Englishes'? Does It Make Any Difference? International Journal of Applied Linguistics, Oslo, v. 22, n. 3, p. 373-39, 2012. Doi: https://doi.org/10.1111/j.1473-4192.2012.00316.x

RAMALHO, V.; RESENDE, V. M. Análise de discurso (para a) crítica: o texto como material de pesquisa. Campinas: Pontes, 2011.

RICENTO, T. (Ed.) An Introduction to Language Policy: Theory and Method. Oxford: Blackwell, 2006a

RICENTO, T. Americanization, Language Ideologies and the Construction of European Identities. In: MAR-MOLINERO, C.; STEVENSON, P. (Ed.). Language Ideologies, Policies and Practices: Language and the Future of Europe. London: Palgrave MacMillan, 2006b. p. 44-57. Doi: https://doi.org/10.1057/9780230523883_4

ROBICHAUD, D.; DE SCHUTTER, H. Language Is Just a Tool! On the Instrumentalist Approach to Language. In: SPOLSKY, B. (Ed.). The Cambridge Handbook of Language Policy. Cambridge: Cambridge University Press, 2012. p. 124146. Doi: ttps://doi.org/10.1017/CBO9780511979026.009

SANTA ANA, O. Brown Tide Rising: Metaphors of Latinos in Contemporary American Public Discourse. Austin: University of Texas Press, 2002.

SCHNEIDER, B. R. Big Business in Brazil: Leveraging Natural Endowments and State Support for International Expansion. In: BRAINARD, L.; MARTINEZDIAZ, L. (Ed.). Brazil as an Economic Superpower? Understanding Brazil's Changing Role in the Global Economy. Washington: Booking Institution Press, 2009. p. 159-186.

SEARGEANT, P. The idea of English in Japan: Ideology and the Evolution of a Global Language. Bristol: Multilingual Matters, 2009. Doi: https://doi. org/10.21832/9781847692030

SEIDLHOFER, B. Research Perspectives on Teaching English as a Lingua Franca. Annual Review of Applied Linguistics, Cambridge, v. 24, p. 209-239, 2004. Doi: https:/ / doi.org/10.1017/S0267190504000145 
SEIDLHOFER, B. Understanding English as a Lingua Franca. New York: Oxford University Press, 2011. Doi: https://doi.org/10.1002/9781405198431.wbeal0243

SHOHAMY, E. Language Policy: Hidden Agendas and New Approaches. London, Routledge, 2006. Doi: https://doi.org/10.4324/9780203387962

SILVA, S. M. W. Cooperação Acadêmica Internacional da Capes na perspectiva do Programa Ciência sem Fronteiras. 2012.113f. Thesis. (M.A. in Education in Chemical Sciences of Life and Health) - Universidade Federal do Rio Grande do Sul, Porto Alegre, 2012.

SILVERSTEIN, M. Language Structure and Linguistic Ideology. In: CLYNE, P.; HANKS, W. F.; HOFBAUER, C. L. (Ed.). In the Elements: A Parasession on Linguistic Units and Levels. Chicago: Chicago Linguistic Society, 1979. p. 193-247.

SZUNDY, P. T. C. The Commodification of English in Brazilian Public Universities: Language Ideologies Entextualized in the Scope of the Program English Without Borders. Revista da Anpoll, Florianópolis, v. 40, n. 1, p. 101-114, Jan./Jun. 2016. Doi: https://doi.org/10.18309/anp.v1i40.1020

THOMPSON, J. B. Studies in Theory of Ideology. Cambridge: Polity Press, 1984.

TOLLEFSON, J. W. Critical Theory in Language Policy. In: RICENTO, T. (ed.). An Introduction to Language Policy: Theory and Method. Oxford: Blackwell, 2006. p. 42-59.

WILEY, T. G. Continuity and Change in the Function of Language Ideologies in the United States. In: RICENTO, T. (Ed.). Ideology, Politics and Language Policies: Focus on English. Amsterdam: J. Benjamins, 2000. p. 135-152.

WODAK, R. Linguistic Analysis in Language Policies. In: RICENTO, T. (Ed.). An Introduction to Language Policy: Theory and Method. Oxford: Blackwell, 2006. p. 170-193.

WODAK, R. What CDA Is About: a Summary of Its History, Important Concepts and Its Developments. In: WODAK, R.; MEYER, M. (ed.). Methods of Critical Discourse Analysis. London: Sage, 2001. p. 1-13. Doi: https://doi. org/10.4135/9780857028020.n1

WOOLARD, K. A. Introduction: Language Ideology as a Field of Inquiry. In: SCHIEFFELIN, B. B.; WOOLARD, K.; KROSKRITY, P. V. (ed.). Language Ideologies: Practice and Theory. New York: Oxford University Press, 1998.

Data de submissão: 30/05/2018. Data de aprovação: 11/03/2019. 